\title{
Peran Kepuasan Sebagai Variabel Mediasi Kualitas Layanan dan Kepercayaan Nasabah terhadap Loyalitas Nasabah Bank Syariah
}

\author{
Tri Winasih"1, Luqman Hakim² \\ 1),2) Pendidikan Ekonomi, Fakultas Ekonomi Universitas Negeri Surabaya, Indonesia \\ Email: tri.17080304027@mhs.unesa.ac.id
}

\begin{abstract}
Abstrak:
Islamic banking is one of the global phenomenon in banking industry which continues to develop. Indonesia at the 9 rank in the world based on total assets and market share of Islamic banking. Nationally, East Java becomes provinces in Indonesia with the largest number of Islamic banks. The composition of young customers has not yet dominated, even though this age group has a role in determining people's attitudes in transacting at Islamic banks. This research purpose to analyze the effect of service quality and customer trust on customer loyalty with customer satisfaction as a mediating variable for students of State Universities in Surabaya. This quantitative research using 210 respondents as samples. Data collected by a questionnaire and analyzed using Partial Least Square (PLS) with the application SmartPLS 3.0. This research conclude that service quality and costumer's trust didn't directly effect customer loyalty but had an indirect effect on customer loyalty through customer satisfaction.

[Perbankan syariah merupakan salah satu fenomena global dalam bidang industri perbankan yang terus mengalami perkembangan. Indonesia menempati urutan ke-9 dunia berdasarkan jumlah aset dan pangsa pasar perbankan syariah. Secara nasional, Jawa Timur menjadi salah satu provinsi di Indonesia dengan jumlah bank syariah terbanyak. Komposisi nasabah dari kalangan muda belum mendominasi, padahal kelompok usia ini memiliki peran dalam menentukan sikap masyarakat dalam bertransaksi di bank syariah. Penelitian ini bermaksud menganalisis pengaruh kualitas layanan dan kepercayaan terhadap loyalitas nasabah dengan kepuasan sebagai variabel mediasi pada mahasiswa Perguruan Tinggi Negeri di Surabaya. Penelitian kuantitatif ini menggunakan 210 responden sebagai sampel penelitian. Data dikumpulkan menggunakan kuesioner dan dianalisis menggunakan Partial Least Square (PLS) dengan aplikasi SmartPLS 3.0. Penelitian ini menyimpulkan kualitas layanan maupun kepercayaan nasabah tidak berpengaruh secara langsung terhadap loyalitas nasabah namun berpengaruh secara tidak langsung melalui kepuasan nasabah.
\end{abstract}

Kata Kunci: Kualitas layanan; kepercayaan nasabah; kepuasan nasabah; loyalitas nasabah. 


\section{PENDAHULUAN}

Perbankan syariah merupakan salah satu fenomena dalam bidang industri perbankan yang terus mengalami perubahan dan perkembangan. Selama tiga dekade terakhir perbankan syariah telah muncul dan mendapat momentum serta menjadi fenomena global dengan penerimaan yang hangat dari nasabah muslim maupun non muslim. ${ }^{1}$ Indonesia termasuk kedalam tiga besar negara yang memiliki pangsa pasar yang signifikan atau memiliki potensi pertumbuhan yang cepat dalam bidang keuangan syariah. Secara global, Indonesia menempati urutan ke-9 berdasarkan aset perbankan syariah dan pangsa pasar global yakni setelah Iran, Arab Saudi, Malaysia, UEA (Uni Emirat Arab), Kuwait, Qatar, Turki dan Bangladesh. ${ }^{2}$

\section{Gambar 1.}

Total Aset dan Pangsa Pasar Perbankan Syariah

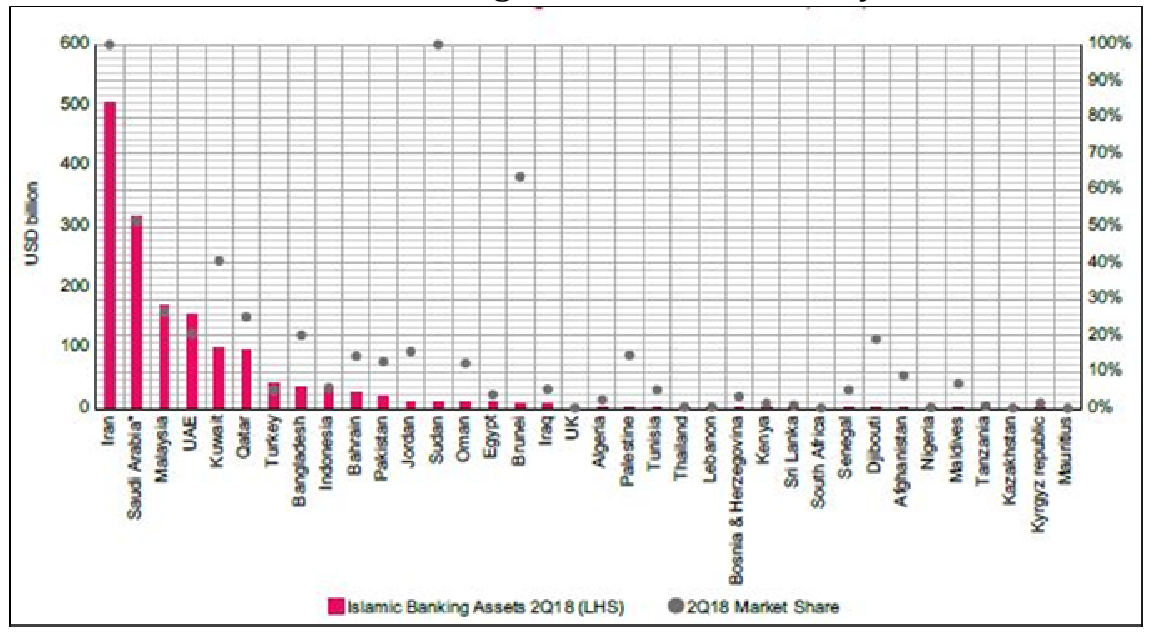

Secara nasional, berdasarkan Laporan Perkembangan Keuangan Syariah Indonesia 2019 yang diterbitkan oleh OJK, perbankan syariah Indonesia selama tahun 2019 menunjukkan pertumbuhan aset sebesar 9,93\% dengan total aset Rp538,32 triliun, total pembiayaan yang disalurkan (PYD) Rp365,13 triliun dan total dana pihak ketiga (DPK) Rp425,29 triliun. Diantara ketiga jenis perbankan syariah, Bank Umum Syariah (BUS) merupakan penyumbang terbesar dari pertumbuhan aset perbankan Syariah dengan memiliki total aset pada tahun 2019 sebesar Rp350,36 triliun. Bank Umum Syariah memiliki 14 institusi dengan jumlah kantor sebanyak 1.919.3 Lebih lanjut berdasarkan Statistik Perbankan Syariah oleh OJK persebaran kantor tersebut paling banyak di Pulau Jawa. Salah satunya Provinsi di Pulau Jawa yang memiliki persebaran kantor bank Syariah paling banyak adalah Jawa Timur, yang mana memiliki 10 BUS dan 194 kantor dengan total dana yang dihimpun pada tahun 2019 sebesar Rp502.606.691juta. ${ }^{4}$

\footnotetext{
${ }^{1}$ Faisal, M., Shabbir, M. S., Javed, S., \& Shabbir, M. F. (2016). Measuring Service Quality and Customer Satisfaction in Pakistan: Evidence Based on Carter Model. International Business Management, 10(20), 5011-5016.

2 Report, S. (2019). Stability report 2019.

3 OJK. (2019). Laporan Perkembangan Keuangan Syariah Indonesia.

${ }^{4}$ BPS Jatim. (2017). Jumlah Bank dan Kantor Bank Menurut Kelompoknya di Provinsi Jawa Timur, 2017. https://jatim.bps.go.id/statictable/2019/10/15/2003/jumlah-bank-dan-kantor-bank-menurutkelompoknya-di-provinsi-jawa-timur-2017-html (diakses 20 November 2020; 10.00 WIB) 206 Iqtishadia: Jurnal Ekonomi dan Perbankan Syariah 
Keseluruhan dana yang dihimpun suatu BUS berasal dari berbagai kalangan, diantaranya kalangan tua (35-55 tahun) dengan 50,85\%, kalangan dewasa (25-34 tahun) dengan 37,6\% dan kalangan muda (18-24 tahun) dengan 11,6\%.5 Kelompok usia muda memang belum mendominasi, namun usia tersebut merupakan usia ideal dalam penetuan sikap masyarakat dalam memilih dan menggunakan jasa bank syariah. Oleh sebab itu, Bank Indonesia gencar dalam memberikan edukasi baik secara formal dengan memasukkan mata kuliah Perbankan Syariah dalam kurikulum pendidikan tinggi, menerbitkan buku-buku referensi mengenai ekonomi dan syariah, serta melakukan berbagai penelitian dan kajian dengan menggandeng berbagai perguruan tinggi. ${ }^{6}$ Selain itu BI juga menyelenggarakan berbagai event-event bertajuk syariah, seperti Expo Islamic Banking (iB) Vaganza, Safari Ramadhan,7 ISEF, FESyar dan kegiatan lain dalam bentuk sosialisasi, kampanye massal, workshop dan talkshow. ${ }^{8}$ Disamping edukasi perbankan syariah oleh Bank Indonesia, suatu lembaga perbankan syariah juga harus segera menyesuaikan diri atas perkembangan sosial agar tetap menjadi pilihan masyarakat dalam persaingan dunia industri yang semakin maju ini. ${ }^{9}$

Menurut Peter Drucker (1979) aktivitas bisnis penting untuk mempertahankan pelanggan serta mengelola hubungan baik dengan pelanggan. ${ }^{10}$ Kondisi dimana pelanggan/nasabah memiliki komitmen bertahan untuk berlangganan produk/jasa tertentu meskipun terdapat pengaruh pemasaran dari produk/jasa lain ini kemudian disebut dengan loyalitas pelanggan atau nasabah.11 Loyalitas nasabah merupakan keadaan yang diharapkan oleh setiap perbankan. ${ }^{12}$ Loyalitas berkaitan erat dengan kepuasan atau ketidakpuasan konsumen dalam melakukan konsumsi barang/jasa. ${ }^{13}$ Loyalitas atau complain merupakan perilaku yang ditunjukkan akibat dari kepuasan yang dirasakan oleh pelanggan setelah melakukan pembelian. ${ }^{14}$

Teori pertukaran sosial mengatakan bahwa suatu pihak akan memberi balasan perlakuan pihak lain sesuai dengan perlakuan yang telah diberikan. Dalam hal perbankan,

${ }^{5}$ Azhar Muttaqin, D. A. D. (2017). Kualitas Produk, Pelayanan dan Nilai Syariah terhadap Persepsi Mahasiswa Ekonomi Islam untuk Menjadi Nasabah Bank Syariah. FALAH: Jurnal Ekonomi Syariah, 2(2), 196. https://doi.org/10.22219/jes.v2i2.5106

6 OJK. (2019). Laporan Ekonomi Dan Keuangan Syariah.

7 OJK. (2019). Laporan Perkembangan Keuangan Syariah Indonesia.

${ }^{8}$ OJK. (2019). Laporan Ekonomi Dan Keuangan Syariah.

${ }^{9}$ Mahyuni, \& Firdaus, M. R. (2014). Loyalitas Nasabah Pada Bank Mumalat Indonesia. Jurnal Wawasan Manajemen, 2(2), 119-137.

${ }^{10}$ Haryono, T. (2010). Pentingnya menjaga dan meningkatkan hubungan baik dengan konsumen dalam masa krisis. JEJAK, 3(c), 75-82.

11 Khotimah, N. (2018). pengaruh religiusitas, kepercayaan, citra perusahaan dan sistem bagi hasil terhadap minat nasabah menabung dan loyalitas di bank syariah mandiri (Studi Kasus Pada Nasabah Bank Syariah Mandiri Gresik). Jurnal Ilmu Ekonomi \& Manajemen, 05(01), 37-48.

12 Ishak, M. Z., \& Azzahroh, E. P. (2017). Pengaruh Kualitas Layanan Terhadap Loyalitas Nasabah Bank Syariah Dengan Kepuasan Nasabah Sebagai Variabel Intervening. Jurnal Ekonomi Dan Bisnis Islam (Journal of Islamic Economics and Business), 3(1), 26. https://doi.org/10.20473/jebis.v3i1.3599

13 Dewi, K. A. N. (2016). PENGARUH KUALITAS LAYANAN TERHADAP LOYALITAS PELANGGAN MELALUI KEPUASAN PELANGGAN SEBAGAI VARIABEL INTERVENING (STUDI PADA PELANGGAN DUNKIN' DONUTS DI SURABAYA DAN SIDOARJO). BISMA - Bisnis Dan Manajemen, 9(1), 43-55.

14 Tjokro, C. I. (2018). DETERMINAN KEPUASAN NASABAH DALAM MEMBENTUK LOYALITAS NASABAH PT BTN CABANG AMBON. Jurnal Manajemen, Ide, Inspirasi (MINDS), 5(1), 1-19. 
menambahkan bahwa ketika layanan yang diberikan bank syariah dianggap sesuai dengan kebutuhan nasabah maka nasabah akan merasakan kepuasan dan akhirnya menjadi loyal dengan melakukan pembelian ulang, merekomendasikan kepada pihak lain dan enggan melakukan perpindahan ke bank lain. ${ }^{15}$

Beberapa persoalan terkait teori pertukaran sosial dalam bidang perbankan, telah ditunjukkan dengan sejumlah temuan sebagai faktor-faktor yang dapat memberi pengaruh loyalitas nasabah. Penelitian Selnes ${ }^{16}$ dengan model teori hubungan variabel kualitas produk, kepuasan, reputasi merek serta loyalitas menemukan bahwa diantara keempat variabel tersebut memiliki hubungan. Sedangkan dalam penelitian Ndubisi ${ }^{17}$ mengemukakan bahwa loyalitas dipengaruhi oleh kepercayaan, komitmen, komunikasi dan pengendalian konflik. Menurut Ningtyas \& Rachmad 18 faktor yang mempengaruhi loyalitas adalah kepercayaan dan kepuasan. Sedangkan menurut Fitriyana et al.19 kualitas layanan dan kualitas produk merupakan faktor yang memberi pengaruh loyalitas. Kemudian Warsito ${ }^{20}$ mengemukakan bahwa kualitas layanan, kepuasan dan citra perusahaan menentukan loyalitas nasabah. Kemudian Hidayat et al. ${ }^{21}$ dalam penelitiannya menyatakan kualitas layanan dan kepercayaan nasabah menentukan loyalitas nasabah. Lain halnya dengan penelitian Dewi ${ }^{22}$ yang mengatakan kualitas dan kepuasan konsumen menentukan loyalitas konsumen. Kemudian Lapasiang at al. ${ }^{23}$ menemukan faktor penentu loyalitas nasabah diantaranya adalah kepercayaan dan komitmen nasabah. Selanjutnya penelitian Ishak \& Azzahroh ${ }^{24}$ menunjukkan bahwa faktor kualitas layanan melalui kepuasan dapat memengaruhi loyalitas

${ }^{15}$ Ishak, M. Z., \& Azzahroh, E. P. (2017). Pengaruh Kualitas Layanan Terhadap Loyalitas Nasabah Bank Syariah Dengan Kepuasan Nasabah Sebagai Variabel Intervening. Jurnal Ekonomi Dan Bisnis Islam (Journal of Islamic Economics and Business), 3(1), 26. https://doi.org/10.20473/jebis.v3i1.3599 ${ }^{16}$ Selnes, F. (1993). An Examination of the Effect of Product Performance on Brand Reputation, Satisfaction and Loyalty. European Journal of Marketing, 27(9), 19-35.

${ }^{17}$ Ndubisi, N. O. (2007). Relationship marketing and customer loyalty. Marketing Intelligence \& Planning, 25(1), 98-106. https://doi.org/10.1108/02634500710722425

${ }^{18}$ Ningtyas, F., \& Rachmad, B. (2011). Pengaruh Kepercayaan, Komitmen, Komunikasi, Penanganan Masalah Dan Kepuasan Nasabah Terhadap Loyalitas Nasabah Bank Muamalat Di Surabaya. Journal of Business and Banking, 1(1), 51. https://doi.org/10.14414/jbb.v1i1.152

${ }^{19}$ Fitriyana, F., Mustafid, \& Suparti. (2013). ANALISIS PENGARUH KUALITAS LAYANAN DAN KUALITAS PRODUK TERHADAP LOYALITAS PELANGGAN PADA ONLINE SHOP MENGGUNAKAN STRUCTURAL EQUATION MODELING. JURNAL GAUSSIAN, 2(2), 98-108.

${ }^{20}$ Warsito, C. (2015). The Image of Financial Institution as Islamic Bank In Mediation Service Quality and Customer Satisfaction on Customer Loyalty in Purwokerto. Al-Iqtishad: Journal of Islamic Economics, 7(2), 217-228. https://doi.org/10.15408/ijies.v7i2.1699

${ }^{21}$ Hidayat, R., Akhmad, S., \& Machmud, M. (2015). Effects of Service Quality, Customer Trust and Customer Religious Commitment on Customers Satisfaction and Loyalty of Islamic Banks in East Java. Al-Iqtishad: Journal of Islamic Economics, 7(2), 151-164. https://doi.org/10.15408/ijies.v7i2.1681

22 Dewi, K. A. N. (2016). PENGARUH KUALITAS LAYANAN TERHADAP LOYALITAS PELANGGAN MELALUI KEPUASAN PELANGGAN SEBAGAI VARIABEL INTERVENING (STUDI PADA PELANGGAN DUNKIN' DONUTS DI SURABAYA DAN SIDOARJO). BISMA - Bisnis Dan Manajemen, 9(1), 43-55.

${ }^{23}$ Lapasiang, D., Moniharapon, S., Loindong, S., \& Ratulangi, U. S. (2017). Pengaruh Kepercayaan Dan Komitmen Terhadap Loyalitas Nasabah Pada Pt. Pegadaian (Persero) Cabang Karombasan Manado. Jurnal EMBA: Jurnal Riset Ekonomi, Manajemen, Bisnis Dan Akuntansi, 5(3), 3068-3077. https://doi.org/10.35794/emba.v5i3.17371

${ }^{24}$ Ishak, M. Z., \& Azzahroh, E. P. (2017). Pengaruh Kualitas Layanan Terhadap Loyalitas Nasabah Bank Syariah Dengan Kepuasan Nasabah Sebagai Variabel Intervening. Jurnal Ekonomi Dan Bisnis Islam (Journal of Islamic Economics and Business), 3(1), 26. https://doi.org/10.20473/jebis.v3i1.3599 
nasabah. Serta penelitian Tjokro ${ }^{25}$ menyatakan bahwa yang memberi pengaruh terhadap loyalitas nasabah diantaranya kepercayaan, kualitas layanan, citra perusahaan nilai nasabah dan keunggulan produk. Oleh sebab itu, penelitian ini menyangka variabel yang memberi pengaruh terhadap loyalitas nasabah perbankan syariah yakni kualitas layanan, kepercayaan nasabah dan kepuasan nasabah sebagai variabel mediasi.

Kualitas layanan adalah faktor utama yang dapat digunakan lembaga perbankan guna bersaing dengan lembaga perbankan lain untuk menjadi lembaga perbankan pilihan masyarakat. Kualitas layanan yang baik disiapkan agar nasabah merasa puas dan tetap loyal terhadap suatu perbankan syariah meskipun persaingan dalam bisnis perbankan syariah semakin tinggi. ${ }^{26}$ Kualitas layanan merupakan hasil evaluasi yang menunjukkan sejauh mana pelayanan suatu lembaga perbankan dalam hal ini telah memenuhi dari apa yang diharapkan oleh nasabah. ${ }^{27}$ Tjiptono menyebutkan bahwa kualitas layanan merupakan usaha guna terpenuhinya kebutuhan serta keinginan dan juga keakuratan penyampaian guna menyeimbangkan dengan harapan pelanggan. ${ }^{28}$ Kemudian Band (1989) dan Kotler (1997) mengemukakan bahwa kualitas berasal dari kebutuhan dan berakhir pada persepsi nasabah, maka kualitas yang baik dapat diketahui dari segi persepsi para nasabah bukan pemberi layanan. ${ }^{29}$ Hasil penelitian Hidayat et al. ${ }^{30}$ dan Okatviani ${ }^{31}$ menyebutkan kualitas layanan secara signifikan mempengaruhi loyalitas nasabah. Penelitian Warsito ${ }^{32}$ memperoleh hasil bahwa kualitas dengan layanan secara bersama mempengaruhi kepuasan dan loyalitas nasabah dengan positif dan signifikan. Selain itu penelitian Tjokro ${ }^{33}$ memperoleh hasil kualitas layanan mempengaruhi dengan positif kepuasan dan loyalitas. Penelitian Aisyah ${ }^{34}$ menyatakan kualitas layanan secara signifikan mempengaruhi langsung kepuasan namun

\footnotetext{
25 Tjokro, C. I. (2018). DETERMINAN KEPUASAN NASABAH DALAM MEMBENTUK LOYALITAS NASABAH PT BTN CABANG AMBON. Jurnal Manajemen, Ide, Inspirasi (MINDS), 5(1), 1-19.
}

${ }^{26}$ Warsito, C. (2015). The Image of Financial Institution as Islamic Bank In Mediation Service Quality and Customer Satisfaction on Customer Loyalty in Purwokerto. Al-Iqtishad: Journal of Islamic Economics, 7(2), 217-228. https://doi.org/10.15408/ijies.v7i2.1699

${ }^{27}$ Hidayat, R., Akhmad, S., \& Machmud, M. (2015). Effects of Service Quality, Customer Trust and Customer Religious Commitment on Customers Satisfaction and Loyalty of Islamic Banks in East Java. Al-Iqtishad: Journal of Islamic Economics, 7(2), 151-164. https://doi.org/10.15408/ijies.v7i2.1681 ${ }^{28}$ Tjiptono, F. (2019). Pemasaran Jasa. Penerbit ANDI.

${ }^{29}$ Tjokro, C. I. (2018). DETERMINAN KEPUASAN NASABAH DALAM MEMBENTUK LOYALITAS NASABAH PT BTN CABANG AMBON. Jurnal Manajemen, Ide, Inspirasi (MINDS), 5(1), 1-19.

${ }^{30}$ Hidayat, R., Akhmad, S., \& Machmud, M. (2015). Effects of Service Quality, Customer Trust and Customer Religious Commitment on Customers Satisfaction and Loyalty of Islamic Banks in East Java. Al-Iqtishad: Journal of Islamic Economics, 7(2), 151-164. https://doi.org/10.15408/ijies.v7i2.1681 ${ }^{31}$ Okatviani, E. (2012). Pengaruh Kualitas Layanan, Kepuasan Nasabah dan Citra Bank Terhadap Loyalitas Nasabah Bank Muamalat di Surabaya. Journal of Business and Banking, 2(2), 171-184. 32 Warsito, C. (2015). The Image of Financial Institution as Islamic Bank In Mediation Service Quality and Customer Satisfaction on Customer Loyalty in Purwokerto. Al-Iqtishad: Journal of Islamic Economics, 7(2), 217-228. https://doi.org/10.15408/ijies.v7i2.1699 33 Tjokro, C. I. (2018). DETERMINAN KEPUASAN NASABAH DALAM MEMBENTUK LOYALITAS NASABAH PT BTN CABANG AMBON. Jurnal Manajemen, Ide, Inspirasi (MINDS), 5(1), 1-19 ${ }^{34}$ Aisyah, M. (2018). Islamic Bank Service Quality and It's Impact on Indonesian Customers' Satisfaction and Loyalty. Al-Iqtishad: Jurnal Ilmu Ekonomi Syariah (Journal of Islamic Economics), 10(2), 367-388. 
tidak mempengaruhi langsung loyalitas nasabah. Sementara itu, penelitian Ridwan et al. ${ }^{35}$ mengatakan kualitas layanan memberi pengaruh tidak signifikan terhadap loyalitas nasabah. Serta penelitian Ishak dan Azzahroh ${ }^{36}$ juga menyatakan kualitas layanan tidak mempengaruhi langsung loyalitas nasabah.

Kepercayaan merupakan aspek yang perlu diperhatikan dalam menjalin hubungan antara pihak bank dengan para stakeholdernya terutama masyarakat sebagai nasabah. Menurut Rotter pada tulisan yang berjudul "A New Scale for the Measurement of Interpersonal Trust" dalam Ningtyas \& Rachmad ${ }^{37}$ mengemukakan bahwa kepercayaan diantara pihak-pihak yang menjalin hubungan merupakan faktor yang sangat penting untuk mencapai efektivitas dalam organisasi sosial yang kompleks. Sedangkan Pradiansyah (1999) dalam Hidayat ${ }^{38}$ kepercayaan diciptakan melalui proses yang bertahap, proses tersebut mencakup dimensi pengalaman masa lalu dalam melakukan konsumsi atas barang/jasa, informasi yang disampaikan oleh pemberi layanan serta antusiasme merupakan respon konsumen setelah mendapatkan pengalaman dan informasi. Hasil penelitian Ningtyas \& Rachmad $^{39}$ menyebutkan bahwa kepercayaan berpengaruh terhadap loyalitas. Begitu pula penelitian Hidayat et al. ${ }^{40}$ mengemukakan kepercayaan memengaruhi langsung dan tidak langsung kepuasan dan loyalitas nasabah. Kemudian penelitian Lapasiang et al.41 memperoleh hasil bahwa kepercayaan secara simultan memberi pangaruh secara signifikan positif terhadap loyalitas nasabah. Serta penelitian Tjokro ${ }^{42}$ dalam penelitiannya juga menyimpulkan kepercayaan mempunyai pengaruh positif secara bersamaan terhadap kepuasan dan loyalitas. Lain halnya dengan penelitian Mahyuni \& Firdaus 43 yang memperoleh hasil bahwa kepercayaan tidak bengaruh secara signifikan terhadap loyalitas nasabah.

\footnotetext{
35 Ridwan, H., Pusporini, \& Samin. (2018). Pengaruh Kepercayaan, Kualitas Pelayanan, Dan Nilai Nasabah Terhadap Loyalitas Pelanggan Melalui Kepuasan Sebagai Variabel Intervening Pada Bank BNI. "Pengabdian Pada Masyarakat Melalui Desiminasi Hasil - Hasil Penelitian Terapan."

${ }^{36}$ Ishak, M. Z., \& Azzahroh, E. P. (2017). Pengaruh Kualitas Layanan Terhadap Loyalitas Nasabah Bank Syariah Dengan Kepuasan Nasabah Sebagai Variabel Intervening. Jurnal Ekonomi Dan Bisnis Islam (Journal of Islamic Economics and Business), 3(1), 26. https://doi.org/10.20473/jebis.v3i1.3599 ${ }^{37}$ Ningtyas, F., \& Rachmad, B. (2011). Pengaruh Kepercayaan, Komitmen, Komunikasi, Penanganan Masalah Dan Kepuasan Nasabah Terhadap Loyalitas Nasabah Bank Muamalat Di Surabaya. Journal of Business and Banking, 1(1), 51. https://doi.org/10.14414/jbb.v1i1.152

${ }^{38}$ Hidayat, R., Akhmad, S., \& Machmud, M. (2015). Effects of Service Quality, Customer Trust and Customer Religious Commitment on Customers Satisfaction and Loyalty of Islamic Banks in East Java. Al-Iqtishad: Journal of Islamic Economics, 7(2), 151-164. https://doi.org/10.15408/ijies.v7i2.1681 ${ }^{39}$ Ningtyas, F., \& Rachmad, B. (2011). Pengaruh Kepercayaan, Komitmen, Komunikasi, Penanganan Masalah Dan Kepuasan Nasabah Terhadap Loyalitas Nasabah Bank Muamalat Di Surabaya. Journal of Business and Banking, 1(1), 51. https://doi.org/10.14414/jbb.v1i1.152

${ }^{40}$ Hidayat, R., Akhmad, S., \& Machmud, M. (2015). Effects of Service Quality, Customer Trust and Customer Religious Commitment on Customers Satisfaction and Loyalty of Islamic Banks in East Java. Al-Iqtishad: Journal of Islamic Economics, 7(2), 151-164. https://doi.org/10.15408/ijies.v7i2.1681 ${ }^{41}$ Lapasiang, D., Moniharapon, S., Loindong, S., \& Ratulangi, U. S. (2017). Pengaruh Kepercayaan Dan Komitmen Terhadap Loyalitas Nasabah Pada Pt. Pegadaian (Persero) Cabang Karombasan Manado. Jurnal EMBA: Jurnal Riset Ekonomi, Manajemen, Bisnis Dan Akuntansi, 5(3), 3068-3077. https://doi.org/10.35794/emba.v5i3.17371

42 Tjokro, C. I. (2018). DETERMINAN KEPUASAN NASABAH DALAM MEMBENTUK LOYALITAS

NASABAH PT BTN CABANG AMBON. Jurnal Manajemen, Ide, Inspirasi (MINDS), 5(1), 1-19.

${ }^{43}$ Mahyuni, \& Firdaus, M. R. (2014). Loyalitas Nasabah Pada Bank Mumalat Indonesia. Jurnal Wawasan Manajemen, 2(2), 119-137.
} 
Kepuasan merupakan indikator bagi terbentuknya loyalitas nasabah. Menurut Tse \& Wilton mengungkapkan bahwa kepuasan/ketidakpuasan konsumen merupakan suatu tanggapan konsumen atas evaluasi kesesuaian antara harapan dan kenyataan setelah mengonsumsi suatu produk/jasa. Begitu pula dengan Oliver (1981) dan Nha Nguyen dan Gaston LeBlanc (1998) dalam yang memandang bahwa kepuasan sebagai reaksi reaksi emosional yang mempengaruhi sikap. ${ }^{44}$ Kemudian Engel et. al (1995) berpendapat bahwa kepuasan yaitu evaluasi setelah melakukan konsumsi. ${ }^{45}$ Menurut Robbins \& Judge menjelaskan bahwa komponen pembentuk sikap seseorang terhadap suatu pdoduk/jasa meliputi komponen kognitif/evaluasi terhadap suatu produk/jasa yang kemudian akan menimbulkan komponen kognitif/kepuasan dan pada akhirnya akan menentukan tindakan/loyalitas nasabah. ${ }^{46}$ Serta penelitian Muzaki \& Ridlwan ${ }^{47}$ menyatakan bahwa kepuasan atas produk dan layanan dapat mendorong sikap loyalitas atau disloyalitas. Maka, peneliti tertarik menghadirkan kepuasan sebagai variabel yang memediasi antara kualitas layanan dan kepercayaan nasabah sebagai variabel independen terhadap loyalitas nasabah sebagai variabel dependen. Penelitian terdahulu Ishak \& Azzahroh ${ }^{48}$ memperoleh hasil $^{2}$ bahwa kepuasan berhasil memediasi kualitas layanan terhadap loyalitas. Sedangkan penelitian Aisyah ${ }^{49}$ mengatakan kepuasan tidak mempengaruhi loyalitas nasabah dan tidak berhasil memediasi kualitas layanan terhadap loyalitas. Begitu pula penelitian Hidayat et al.50 menyatakan bahwa kepuasan dapat memediasi kepercayaan terhadap loyalitas namun kepuasan tidak memediasi komitmen terhadap loyalitas nasabah.

Berdasarkan uraian diatas, maka peneliti bertujuan mengkaji dan melaksanakan penelitian mengenai faktor yang diduga memengaruhi loyalitas nasabah bank syariah khususnya kalangan usia muda dalam hal ini mahasiswa Perguruan Tinggi Negeri di Surabaya yakni kualitas layanan dan kepercayaan nasabah secara langsung maupun melalui kepuasan nasabah sebagai variabel mediasi terhadap loyalitas nasabah

\footnotetext{
${ }^{44}$ Warsito, C. (2015). The Image of Financial Institution as Islamic Bank In Mediation Service Quality and Customer Satisfaction on Customer Loyalty in Purwokerto. Al-Iqtishad: Journal of Islamic Economics, 7(2), 217-228. https://doi.org/10.15408/ijies.v7i2.1699

${ }^{45}$ Dewi, K. A. N. (2016). PENGARUH KUALITAS LAYANAN TERHADAP LOYALITAS PELANGGAN MELALUI KEPUASAN PELANGGAN SEBAGAI VARIABEL INTERVENING (STUDI PADA PELANGGAN DUNKIN' DONUTS DI SURABAYA DAN SIDOARJO). BISMA - Bisnis Dan Manajemen, 9(1), 43-55. ${ }^{46}$ Ishak, M. Z., \& Azzahroh, E. P. (2017). Pengaruh Kualitas Layanan Terhadap Loyalitas Nasabah Bank Syariah Dengan Kepuasan Nasabah Sebagai Variabel Intervening. Jurnal Ekonomi Dan Bisnis Islam (Journal of Islamic Economics and Business), 3(1), 26. https://doi.org/10.20473/jebis.v3i1.3599 47 Muzaki, M. H., \& Ridlwan, A. A. (2019). Determinan Faktor Yang Memengaruhi Disloyalitas Nasabah Bank Pembiayaan Rakyat Syariah. Iqtishadia, 6(1), 1-12.

https://doi.org/10.19105/iqtishadia.v6i1.2338

${ }^{48}$ Ishak, M. Z., \& Azzahroh, E. P. (2017). Pengaruh Kualitas Layanan Terhadap Loyalitas Nasabah Bank Syariah Dengan Kepuasan Nasabah Sebagai Variabel Intervening. Jurnal Ekonomi Dan Bisnis Islam (Journal of Islamic Economics and Business), 3(1), 26. https://doi.org/10.20473/jebis.v3i1.3599

${ }^{49}$ Aisyah, M. (2018). Islamic Bank Service Quality and It's Impact on Indonesian Customers' Satisfaction and Loyalty. Al-Iqtishad: Jurnal Ilmu Ekonomi Syariah (Journal of Islamic Economics), 10(2), 367-388.

${ }^{50}$ Hidayat, R., Akhmad, S., \& Machmud, M. (2015). Effects of Service Quality, Customer Trust and Customer Religious Commitment on Customers Satisfaction and Loyalty of Islamic Banks in East Java. Al-Iqtishad: Journal of Islamic Economics, 7(2), 151-164. https://doi.org/10.15408/ijies.v7i2.1681
} 


\section{METODE PENELITIAN}

Penelitian kuantitatif ini adalah jenis penelitian dengan angka-angka sebagai data penelitiannya dan pada tahap analisinya dengan metode statistik. Populasi penelitian yaitu mahasiswa aktif Perguruan Tinggi Negeri di Surabaya yang menjadi nasabah di Bank Syariah. Penelitian ini memiliki populasi infinite yang mana tidak diketahui secara pasti jumlah pupulasinya. Maka, pengambilan sampel dengan purposive sampling. Penentuan jumlah sampel menggunakan teori Malhotra51 yang menyebutkan studi pengujian pasar dengan minimum 200 responden, kemudian peneliti menambah error 5\% sehingga penilitian ini menggunakan jumlah sampel sebanyak 210 responden. Metode pengumpulan data dengan memberikan kuesioner. Hal ini berarti peneliti memperoleh sumber data langsung dari sumber data asli. ${ }^{52}$

Berikut model rancangan pada penelitian ini :

Gambar 2.

Rancangan Penelitian

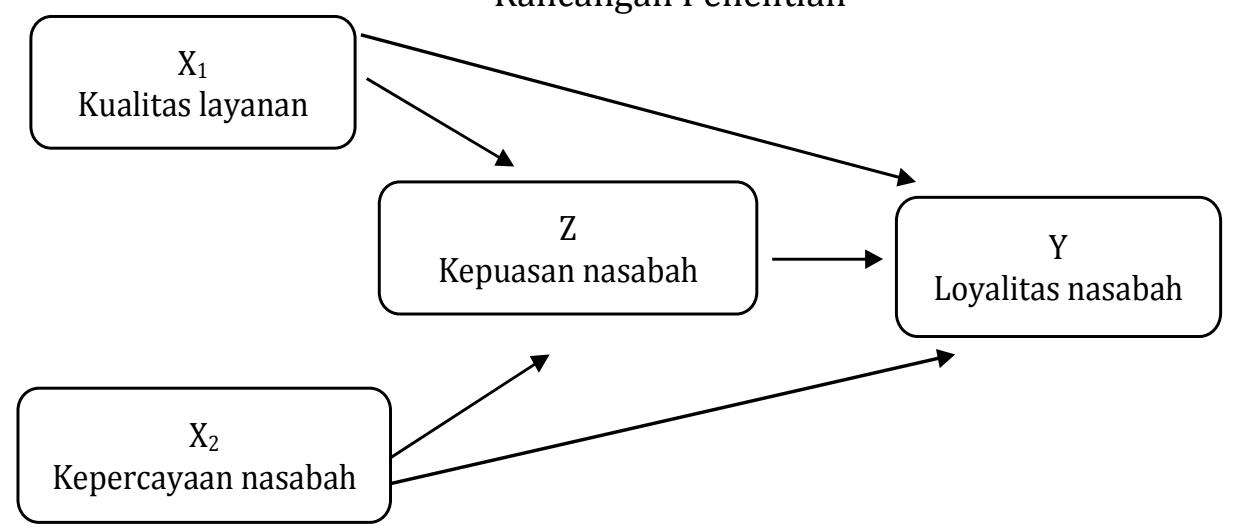

Instrumen penelitian ini meliputi variabel kualitas layanan dengan 34 item pertanyaan, variabel kepercayaan nasabah 12 item pertanyaan, variabel kepuasan nasabah 3 item pertanyaan dan variabel loyalitas nasabah 5 item pertanyaan pada. Pengukuran instrumen menggunakan skala Likert 5.

Tabel 1.

Skor Jawaban Skala Linkert

\begin{tabular}{clc}
\hline No & \multicolumn{1}{c}{ Kriteria } & Skor \\
\hline $\mathbf{1}$ & Sangat Setuju & 5 \\
$\mathbf{2}$ & Setuju & 4 \\
$\mathbf{3}$ & Ragu-ragu & 3 \\
$\mathbf{4}$ & Tidak Setuju & 2 \\
$\mathbf{5}$ & Sangat Tidak Setuju & 1 \\
\hline
\end{tabular}

Indikator dalam instrumen pengumpulan data penelitian ini:

1. Kualitas layanan

\footnotetext{
${ }^{51}$ Malhotra, N. K. (2017). Riset Pemasaran Pendekatan Terapan. Indeks 52 Sugiyono. (2018). Metode Penelitian Kuantitatif, Kualitatif dan R\&D. Alfabeta. 212 Iqtishadia: Jurnal Ekonomi dan Perbankan Syariah Vol.8 No.2 Desember 2021
} 
Menggunakan model CARTER dalam penelitian Cahyani ${ }^{53}$ yakni model untuk mengukur kualitas layanan di bank syariah yaitu Kepatuhan (Compliance), Jaminan (Assurance), Keandalan (Reliability), Keberwujudan (Tangible), Empati (Empathy) dan Daya Tanggap (Responsiveness).

2. Kepercayaan nasabah

Pada variabel ini peneliti menggunakan indikator yang dikembangkan dalam penelitian Khotimah ${ }^{54}$ yang meliputi 5 dimensi yaitu benevolence (niat baik), integrity (integritas), competence (kompetensi), willingness to depend (kesediaan bergantung kepada bank syariah sebagai penerima risiko), dan subjective probability of depending (kesediaan secara subjektif untuk bergantung kepada bank syariah).

3. Kepuasan nasabah

Indikator kepuasan nasabah menggunakan indikator yang dikembangkan oleh Engel, et.al (1995) dan Kotler (1997) dalam penelitian Tjokro55 yang meliputi : kepuasan keseluruhan, kepuasan produk dan perbandingan antara harapan dan kenyataan.

4. Loyalitas nasabah

Loyalitas diukur dengan menggunakan indikator dalam penelitian Cahniati \& Aprianti ${ }^{6}$ yang meliputi pembelian ulang, rekomendasi dan kesetiaan terhadap bank syariah.

Pengukuran instrumen penelitian ini dengan uji validitas dan reliabilitas berbantuan aplikasi Soland 2.1. Uji ini guna mengetahui instrumen yang baik pada setiap pertanyaan dari indikator-indikator diatas, sehingga data yang didapat sesuai kondisi sebenarnya. Analisis data dengan teknik Partial Least Square (PLS) berbantuan aplikasi SmartPLS 3.0.

\section{HASIL DAN PEMBAHASAN}

Terdapat 210 mahasiswa menjadi sampel dalam penelitian ini yaitu Universitas Negeri Surabaya sebanyak 141 mahasiswa, Universitas Islam Negeri Sunan Ampel sebanyak 40 mahasiswa, Universitas Airlangga sebanyak 27 mahasiswa dan Universitas Pembangunan Negara Veteran Jawa Timur sebanyak 2 mahasiswa.

Pada penelitian ini kevalidan dan keadalan instumen diuji dengan menggunakan aplikasi Soland 2.1. Hasil dari uji validitas menunjukkan 1 item pertanyaan dari variable kepercayaan nasabah tidak valid karena $r$ terkoreksi hanya 0,2922. Sedangkan 53 item yang lain dikatakan valid karena $r$ atau $r$ terkoreksi menunjukkan angka $>0.3$ serta seluruh variabel dikatakan reliabel dengan menunjukkan angka koefisien alpha cronbach $>0.6$, sehingga item dalam kuesioner dapat digunakan untuk mengambil data penelitian.

\footnotetext{
${ }^{53}$ Cahyani, P. D. (2016). Tingkat Kepuasan Nasabah Terhadap Kualitas Layanan Perbankan Syariah di Yogyakarta. Esensi : Jurnal Bisnis Dan Manajemen, 6(2), 151-162. https://doi.org/10.15408/ess.v6i2.3570

${ }^{54}$ Khotimah, N. (2018). pengaruh religiusitas, kepercayaan, citra perusahaan dan sistem bagi hasil terhadap minat nasabah menabung dan loyalitas di bank syariah mandiri (Studi Kasus Pada Nasabah Bank Syariah Mandiri Gresik). Jurnal Ilmu Ekonomi \& Manajemen, 05(01), 37-48.

55 Tjokro, C. I. (2018). DETERMINAN KEPUASAN NASABAH DALAM MEMBENTUK LOYALITAS

NASABAH PT BTN CABANG AMBON. Jurnal Manajemen, Ide, Inspirasi (MINDS), 5(1), 1-19.

${ }^{56}$ Cahniati, M., \& Aprianti, K. (2020). Pengaruh Kualitas Produk dan Kualitas Pelayanan Terhadap Loyalitas Pelanggan di Soehendar Coffe. Journal of Applied Business and Economics (JABE), 6(4), 354361.
} 
Gambar 3.

Model Penelitian SmartPLS

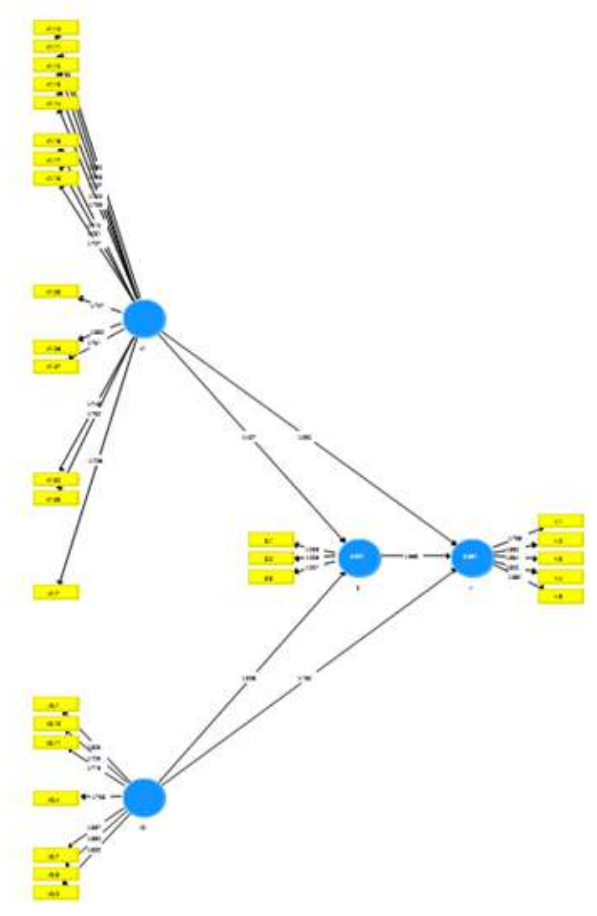

Pada analisis PLS dilakukan dengan 3 tahap yakni evaluasi outer model, inner model dan pengujian hipotesis.

\section{Evaluasi outer model}

Evaluasi outer model meliputi uji convergent validity, discriminant validity, composite reliability. ${ }^{57}$

Uji validitas konvergen diketahui dari nilai loading factor atau outer loading. Nilai loading factor indikator harus $>0.7$ untuk dapat dikatakan ideal/valid sebagai pengukur konstruk. ${ }^{58}$ Hasil pengolahan data menunjukkan bahwa pada variabel kualitas layanan dan kepercayaan terdapat beberapa indikator yang tidak memenuhi validitas konvergen, dengan memiliki nilai loading factor $<0.7$, sehingga harus dikeluarkan dari model. Setelah indikator dengan loading factor $<0.7$ tersebut dikeluarkan, maka nilai AVE masing-masing variabel adalah sebagai berikut :

Tabel 2.

Nilai AVE

\begin{tabular}{clc}
\hline No & \multicolumn{1}{c}{ Variabel } & Nilai AVE \\
\hline $\mathbf{1}$ & Kualitas Layanan & 0.552 \\
$\mathbf{2}$ & Kepercayaan Nasabah & 0.626
\end{tabular}

\footnotetext{
${ }^{57}$ Khotimah, N. (2018). pengaruh religiusitas, kepercayaan, citra perusahaan dan sistem bagi hasil terhadap minat nasabah menabung dan loyalitas di bank syariah mandiri (Studi Kasus Pada Nasabah Bank Syariah Mandiri Gresik). Jurnal Ilmu Ekonomi \& Manajemen, 05(01), 37-48.

${ }^{58}$ Ghozali, I., \& Latan, H. (2015). Partial Least Squares : Konsep, Teknik dan Aplikasi Menggunakan Program SmartPLS 3.0 (Edisi 2). Universitas Diponegoro. 
Pengaruh Kualitas Layanan dan Kepercayaan Nasabah terhadap Loyalitas Nasabah dengan Kepuasan Nasabah sebagai

\begin{tabular}{lll}
3 & Kepuasan Nasabah & 0.697 \\
4 & Loyalitas Nasabah & 0.835 \\
\hline
\end{tabular}

Berdasarkan hasil uji nilai outer loading indikator dan nilai AVE $>0.5$ maka indikator dalam variabel ini dapat dikatakan dapat diterima/valid dan memenuhi validitas.

Sedangkan uji validitas diskriminan dilakukan dengan melihat cross loading. Indikator penelitian ini dapat dikatakan valid karena nilai cross loading indikator pada variabel pembentuknya jika dibandingkan dengan variabel lainnya menunjukkan nilai yang lebih besar. Hal ini berarti indikator penelitian ini dalam menyusun setiap variabelnya menunjukkan validitas diskriminan yang baik.

Uji reliabilitas komposit dilihat dari nilai latent variabel coefficient. Penelitian ini memenuhi kriteria dari uji dengan memiliki reliabilitas komposit (composite reliability) dan cronbach alpha bernilai $>0.7$ sebagai beriku :

Tabel 3.

Nilai Composite Reliability dan Cronbach Alpha

\begin{tabular}{clcc}
\hline No & \multicolumn{1}{c}{ Variabel } & $\begin{array}{c}\text { Composite } \\
\text { reliability }\end{array}$ & $\begin{array}{c}\text { Cronbach } \\
\text { alpha }\end{array}$ \\
\hline 1 & Kualitas layanan & 0.945 & 0.937 \\
\hline 2 & Kepercayaan nasabah & 0.921 & 0.900 \\
\hline 3 & Kepuasan nasabah & 0.920 & 0.892 \\
\hline 4 & Loyalitas nasabah & 0.938 & 0.901 \\
\hline
\end{tabular}

Berdasarkan hasil pengolahan tersebut dapat dikatakan bahwa konstruk reliabel dan uji composite reliability dapat diterima.

\section{Evaluasi inner model}

Evaluasi inner model meliputi R² dan Goodness of Fit (GoF). ${ }^{59}$

Besar pengaruh variabel independen terhadap variabel dependen dalam penelitian ini dapat diketahui melalui uji R2 berikut :

Tabel 4.

Nilai R Square

\begin{tabular}{ccc}
\hline No & Variabel & R Square $\mathbf{( R}^{\mathbf{2}} \mathbf{0}$ \\
\hline $\mathbf{1}$ & Loyalitas Nasabah & 0.561 \\
$\mathbf{2}$ & Kepuasan Nasabah & 0.591 \\
\hline
\end{tabular}

Hasil uji R2 ini dapat disimpulkan kualitas layanan (X1) dan kepercayaan (X2) mampu menjelaskan varians loyalitas nasabah sebesar 56,1\%. Sedangkan kualitas layanan (X1) dan kepercayaan (X2) mampu menjelaskan varians kepuasan nasabah sebesar 59,1\%. Sehingga hasil ini menyimpulkan bahwa model memiliki R Square yang moderat.

Selanjutnya untuk menguji kekuatan prediksi model dengan melihat nilai $Q^{2}\left(Q^{-}\right.$ Square) berikut :

$$
\mathrm{Q}^{2}=1-\left(1-\mathrm{R} 1^{2}\right)\left(1-\mathrm{R} 2^{2}\right)
$$

\footnotetext{
${ }^{59}$ Khotimah, N. (2018). pengaruh religiusitas, kepercayaan, citra perusahaan dan sistem bagi hasil terhadap minat nasabah menabung dan loyalitas di bank syariah mandiri (Studi Kasus Pada Nasabah Bank Syariah Mandiri Gresik). Jurnal Ilmu Ekonomi \& Manajemen, 05(01), 37-48.
} 
Tri Winasih, Luqman Hakim

$$
\begin{aligned}
& =1-(1-0.314721)(1-0.349281) \\
& =1-(0.685279)(0.650719) \\
& =1-0.4459 \\
& =0.5541
\end{aligned}
$$

Hasil Q square diatas menyimpulkan bahwa $\mathrm{Q}^{2}>0$, maka model mempunyai predictive relevance kuat.

Kemudian, untuk menilai besaran pengaruh dengan melihat nilai $\mathrm{F}^{2}$ (F- Square) yang menunjukkan nilai sebagai berikut :

Tabel. 5

F-Square

\begin{tabular}{clcc}
\hline No & \multicolumn{1}{c}{ Variabel } & $\begin{array}{r}\text { Loyalitas } \\
\text { Nasabah }\end{array}$ & Kepuasan Nasabah \\
\hline 1 & Kualitas Layanan & $0.002(\mathrm{kecil})$ & $0.122($ menengah) \\
\hline 2 & Kepercayaan Nasabah & 0.020 (kecil) & 0.115 (menengah) \\
\hline 3 & Kepuasan Nasabah & 0.295 (kuat) & \\
\hline
\end{tabular}

Sedangkan uji Goodness of Fit (GoF) dapat dililhat dari perkalian nilai akar rata-rata communalities dengan akar rata-rata r-square, sebagai berikut :

$$
\begin{aligned}
\mathrm{GoF}=\sqrt{ }((\mathrm{Com} / \mathrm{n}) \times(\mathrm{R} 2 / \mathrm{n}) \\
\\
\mathrm{GoF}=\sqrt{ }(((0.552+0.626+0.697+0.835): 4) \times((0.561+0.591): 2)) \\
\mathrm{GoF}=\sqrt{ }(\times 0.5785) \\
\mathrm{GoF}=0.6246919240=0.625
\end{aligned}
$$

Berdasarkan nilai GoF 0.625 tersebut maka termasuk dalam kriteria GoF yang besar yang berarti menunjukkan bahwa semakin sesuai dalam menggambarkan sampel penelitian.

\section{Pengujian Hipotesis}

Pengujian hipotesis penelitian ini mencakup 2 pengujian hipotesis, yakni uji hipotesis atas pengaruh langsung (direct effect) dan tidak langsung (indirect effect).

Pengaruh langsung:

Tabel 6.

Path Coefficients (Koefisien Jalur)

\begin{tabular}{ccccc}
\hline No & Sampel Asli(0) & $\begin{array}{c}\text { T- } \\
\text { statistics }\end{array}$ & P-Value & Keterangan \\
\hline 1 & $\mathrm{X} 1 \rightarrow \mathrm{Y}$ & 0.479 & 0.632 & Tidak berpengaruh \\
\hline 2 & $\mathrm{X} 1 \rightarrow \mathrm{Z}$ & 4.605 & 0.000 & Berpengaruh signifikan \\
\hline 3 & $\mathrm{X} 2 \rightarrow \mathrm{Y}$ & 1.738 & 0.083 & Tidak berpengaruh \\
\hline 4 & $\mathrm{X} 2 \rightarrow \mathrm{Z}$ & 4.285 & 0.000 & Berpengaruh signifikan \\
\hline 5 & $\mathrm{Z} \rightarrow \mathrm{Y}$ & 6.618 & 0.000 & Berpengaruh signifikan \\
\hline
\end{tabular}

Pengaruh tidak langsung:

Tabel 7.

Spesific Indirect Effect (Pengaruh Tidak Langsung)

\begin{tabular}{ccccc}
\hline No & Sampel Asli(0) & $\begin{array}{c}\text { T- } \\
\text { statistics }\end{array}$ & P-Value & Keterangan \\
\hline 1 & $\mathrm{X} 1 \rightarrow \mathrm{Z} \rightarrow \mathrm{Y}$ & 3.755 & 0.000 & Berpengaruh \\
\hline 2 & $\mathrm{X} 2 \rightarrow \mathrm{Z} \rightarrow \mathrm{Y}$ & 3.511 & 0.000 & Berpengaruh \\
\hline
\end{tabular}


Berdasarkan tabel diatas diketahui hasil dari uji analisis menggunakan aplikasi SmartPLS 3.0 atas jawaban dari hipotesis dalam penelitian ini. Berikut pembahasan hasil uji hipotesis tersebut :

\section{Pengaruh Kualitas Layanan terhadap Loyalitas Nasabah}

Hipotesis pertama adalah pengujian pengaruh kualitas layanan (X1) terhadap loyalitas nasabah $(\mathrm{Y})$, yang mana nilai T-Statistic lebih kecil dari T-tabel $(0.479<1.971)$ dengan p-value $0.632>0.05$, artinya $\mathrm{H} 1$ ditolak atau tidak berpengaruh. Indikator-indikator yang digunakan dalam mencari data yang termasuk kedalam dimensi kepatuhan (compliance), jaminan (assurance), keandalan (reliability), keberwujudan (tangible), empati (emphaty) dan daya tanggap (responsiveness) tidak dapat memberi pengaruh langsung terhadap loyalitas nasabah bank syariah. Hasil tersebut konsisten dengan penelitian terdahulu Ridwan et al $^{60}$ yang memperoleh hasil kualitas layanan memiliki pengaruh tidak signifikan terhadap loyalitas nasabah dengan nilai signifikansi $0.079>0.05$. Selain itu juga sesuai dengan penelitian Ishak \& Azzahroh ${ }^{61}$ yang mana p-value dari kualitas layanan terhadap loyalitas nasabah adalah $0.302>0.05$ sehingga tidak berpengaruh.

\section{Pengaruh Kualitas Layanan terhadap Kepuasan Nasabah}

Hipotesis kedua adalah pengujian pengaruh kualitas layanan (X1) terhadap kepuasan nasabah (Z) menunjukkan nilai T-Statistic lebih besar dari T-tabel $(4.605>1.971)$ serta pvalue $0.000<0.05$, artinya $\mathrm{H} 2$ diterima atau berpengaruh. Hal ini berarti semakin baik kualitas layanan (X1) sangat berpengaruh terhadap kepuasan nasabah (Z). Selain itu Indikator-indikator yang digunakan dalam mencari data yang termasuk kedalam dimensi kepatuhan (compliance), jaminan (assurance), keandalan (reliability), keberwujudan (tangible), empati (emphaty) dan daya tanggap (responsiveness) berhasil memberi pengaruh kualitas layanan terhadap kepuasan nasabah. Hal ini sesuai penelitian Ishak \& Azzahroh ${ }^{62}$ yang mana kualitas layanan berpengaruh terhadap kepuasan nasabah dengan nilai p-value 0.008. Ini memperkuat bahwasanya kualitas layanan bank syariah dengan menerapkan prinsip -prinsip syariah, pelayanan yang sopan, aman, nyaman, cepat, karyawan yang peduli, perhatian serta tampilan menarik dari karyawan maupun fisik perbankan maka nasabah akan merasakan kepuasan.

\section{Pengaruh Kepercayaan Nasabah terhadap Loyalitas Nasabah}

Hipotesis ketiga adalah pengujian pengaruh kepercayaan (X2) terhadap loyalitas nasabah (Y), yang mana menunjukkan nilai T-Statistic lebih kecil dari T-tabel $(1.738<1.971)$ serta p-value 0.083> 0.05, artinya H3 ditolak atau tidak berpengaruh. Pada variabel ini

\footnotetext{
60 Ridwan, H., Pusporini, \& Samin. (2018). Pengaruh Kepercayaan, Kualitas Pelayanan, Dan Nilai Nasabah Terhadap Loyalitas Pelanggan Melalui Kepuasan Sebagai Variabel Intervening Pada Bank BNI. "Pengabdian Pada Masyarakat Melalui Desiminasi Hasil - Hasil Penelitian Terapan."

${ }^{61}$ Ishak, M. Z., \& Azzahroh, E. P. (2017). Pengaruh Kualitas Layanan Terhadap Loyalitas Nasabah Bank Syariah Dengan Kepuasan Nasabah Sebagai Variabel Intervening. Jurnal Ekonomi Dan Bisnis Islam (Journal of Islamic Economics and Business), 3(1), 26. https://doi.org/10.20473/jebis.v3i1.3599 62 Ishak, M. Z., \& Azzahroh, E. P. (2017). Pengaruh Kualitas Layanan Terhadap Loyalitas Nasabah Bank Syariah Dengan Kepuasan Nasabah Sebagai Variabel Intervening. Jurnal Ekonomi Dan Bisnis Islam (Journal of Islamic Economics and Business), 3(1), 26. https://doi.org/10.20473/jebis.v3i1.3599
} 
indikator dalam kepercayaan nasabah (X2) diantaranya prioritas bank syariah untuk mengutamakan kepentingan nasabah (X2.1), kesesuaian produk yang tersedia dengan penawaran produk melalui iklan (X2.4), penyediaan produk atau jasa yang berkualitas (X2.7), kemampuan bank syariah dalam menjaga kepercayaan nasabah dalam menggunakan produk atau layanan (X2.8), kesediaan nasabah untuk memberikan kepercayaan kepada bank syariah sebagai penerima risiko atas transaksi perbankan (X2.9), kesediaan nasabah untuk memberikan informasi pribadi kepada karyawan bank syariah (X2.10) dan kesediaan nasabah untuk mengikuti sran yang diberikan karyawan bank (X2.11) tidak dapat memberi pengaruh langsung kepercayaan nasabah terhadap loyalitas nasabah. Hasil ini selaras dengan penelitian Mahyni \& Firdaus ${ }^{63}$ yang juga membutikan kepercayaan nasabah tidak berpengaruh secara signifikan terhadap loyalitas nasabah dengan memiliki p-value sebesar 0.034 .

\section{Pengaruh Kepercayaan Nasabah terhadap Kepuasan Nasabah}

Hipotesis keempat adalah pengujian pengaruh kepercayaan nasabah (X2) terhadap kepuasan nasabah (Z), yang mana menunjukkan nilai T-Statistic lebih besar dari T-tabel (4.285>1.971) serta p-value $0.000<0.5$, artinya $\mathrm{H} 4$ diterima atau berpengaruh. Hasil ini sesuai dengan penelitian terdahulu oleh Hidayat et al. ${ }^{64}$ yang mana hubungan kepercayaan nasabah terhadap kepuasan nasabah memiliki koefisien jalur secara langsung sebesar 0.18 , yang mana dalam penelitiannya menyebutkan bahwa jika suatu manajemen bank syariah menginginkan kepuasan nasabah meningkat maka perlu meningkatkan kepercayaan nasabah dengan mengedepankan kejujuran karyawan, tidak memanfaatkan keuntungan jangka pendek, dan lain-lain. Disamping itu, juga dapat dinyatakan bahwa indikator kepercayaan nasabah (X2) dalam penelitian ini, diantaranya prioritas bank syariah untuk mengutamakan kepentingan nasabah (X2.1), kesesuaian produk yang tersedia dengan penawaran produk melalui iklan (X2.4), penyediaan produk atau jasa yang berkualitas (X2.7), kemampuan bank syariah dalam menjaga kepercayaan nasabah dalam menggunakan produk atau layanan (X2.8), kesediaan nasabah untuk memberikan kepercayaan kepada bank syariah sebagai penerima risiko atas transaksi perbankan (X2.9), kesediaan nasabah untuk memberikan informasi pribadi kepada karyawan bank syariah (X2.10) dan kesediaan nasabah untuk mengikuti sran yang diberikan karyawan bank (X2.11) berhasil memberi pengaruh kepercayaan nasabah terhadap kepuasan nasabah bank syariah.

\section{Pengaruh Kepuasan Nasabah terhadap Loyalitas Nasabah}

Hipotesis kelima adalah pengujian pengaruh kepuasan nasabah (Z) terhadap loyalitas nasabah (Y), yang mana menunjukkan nilai T-Statistic lebih besar dari T-tabel $(6.618>1.971)$ serta p-value $0.000<0.05$, artinya H5 diterima atau berpengaruh. Kepuasan nasabah yang semakin tinggi akan mnimbulkan loyalitas nasabah juga semakin tinggi. Hasil ini selaras dengan penelitian Ishak \& Azzahroh ${ }^{65}$ yang menunjukkan p-value $<0.001$ atas hubungan

\footnotetext{
${ }^{63}$ Mahyuni, \& Firdaus, M. R. (2014). Loyalitas Nasabah Pada Bank Mumalat Indonesia. Jurnal Wawasan Manajemen, 2(2), 119-137.

${ }^{64}$ Hidayat, R., Akhmad, S., \& Machmud, M. (2015). Effects of Service Quality, Customer Trust and Customer Religious Commitment on Customers Satisfaction and Loyalty of Islamic Banks in East Java. Al-Iqtishad: Journal of Islamic Economics, 7(2), 151-164. https://doi.org/10.15408/ijies.v7i2.1681 ${ }^{65}$ Ishak, M. Z., \& Azzahroh, E. P. (2017). Pengaruh Kualitas Layanan Terhadap Loyalitas Nasabah Bank Syariah Dengan Kepuasan Nasabah Sebagai Variabel Intervening. Jurnal Ekonomi Dan Bisnis Islam (Journal of Islamic Economics and Business), 3(1), 26. https://doi.org/10.20473/jebis.v3i1.3599 218 Iqtishadia: Jurnal Ekonomi dan Perbankan Syariah Vol.8 No.2 Desember 2021
} 
variabel kepuasan nasabah terhadap loyalitas nasabah. Namun penelitian ini bertolak belakang dengan Aisyah ${ }^{66}$ dimana menyimpulkan kepuasan nasabah tidak memiliki pengaruh terhadap loyalitas nasabah dengan nilai signifikansi 0.393 (>0.05). Disamping itu, hasil ini menunjukkan bahwa indikator kepuasan nasabah yang meliputi kepuasan keseluruhan atas layanan bank syariah (Y.1), kepuasan atas produk bank syariah (Y.2), dan kepuasan atas pemenuhan harapan (Y.3) berhasil memengaruhi loyalitas nasabah.

\section{Pengaruh Kualitas Layanan terhadap Loyalitas Nasabah melalui Kepuasan Nasabah}

Hipotesis keenam adalah pengujian pengaruh kualitas layanan (X1) terhadap loyalitas nasabah (Y) melalui kepuasan nasabah (Z), yang mana menunjukkan nilai T-Statistic lebih besar dari T-tabel $(3.755>1.971)$ serta p-value $0.000<0.05$, artinya H6 diterima atau kualitas layanan (X1) berpengaruh terhadap loyalitas nasabah (Y) melalui kepuasan nasabah (Z). Berdasarkan hasil analisis dapat disimpulkan bahwa variabel kepuasan nasabah (Z) mampu memediasi sempurna (complete mediation). Mediasi sempurna adalah keadaan yang mana variabel mediasi mampu mempengaruhi atau meningkatkan pengaruh antara variabel dependen dan independen. Hasil ini selaras dengan penelitian oleh Ishak \& Azzahroh ${ }^{67}$ yang memberi kesimpulan bahwa kepuasan nasabah mampu menjadi mediator untuk meningkatkan pengaruh terhadap loyalitas nasabah. Artinya kualitas layanan tidak mempengaruhi secara langsung loyalitas nasabah, namun kepuasan juga menjadi perantara antara kualitas layanan untuk mempengaruhi loyalitas nasabah. Sehingga baik buruknya kualitas layanan dapat mempengaruhi kepuasan nasabah dan akhirnya akan mempengaruhi loyalitas nasabah juga dengan ditandai dengan sikap nasabah untuk bersedia membeli ulang dan memberi rekomendasi orang disekitarnya untuk melakukan transaksi di bank syariah.

\section{Pengaruh Kepercayaan Nasabah terhadap Loyalitas Nasabah melalui Kepuasan Nasabah}

Hipotesis ketujuh adalah pengujian pengaruh kepercayaan Nasabah (X2) terhadap loyalitas nasabah (Y) melalui kepuasan nasabah (Z), yang mana menunjukkan nilai T-Statistic lebih besar dari T-tabel $(3.511>1.971)$ serta p-value $0.000>0.05$, artinya $\mathrm{H} 7$ diterima atau kepercayaan nasabah (X2) berpengaruh secara signifikan terhadap loyalitas nasabah (Y) melalui kepuasan nasabah (Z). Hasil analisis ini juga mengatakan variabel kepuasan nasabah (Z) mampu memediasi sempurna (complete mediation) kepercayaan nasabah terhadap loyalitas nasabah (Y). Hasil ini selaras dengan penelitian Hidayat et al.68 yang mana menyatakan kepercayaan juga berpengaruh secara tidak langsung terhadap loyalitas nasabah melalui kepuasan nasabah.

\footnotetext{
${ }^{67}$ Ishak, M. Z., \& Azzahroh, E. P. (2017). Pengaruh Kualitas Layanan Terhadap Loyalitas Nasabah Bank Syariah Dengan Kepuasan Nasabah Sebagai Variabel Intervening. Jurnal Ekonomi Dan Bisnis Islam (Journal of Islamic Economics and Business), 3(1), 26. https://doi.org/10.20473/jebis.v3i1.3599 ${ }^{68}$ Hidayat, R., Akhmad, S., \& Machmud, M. (2015). Effects of Service Quality, Customer Trust and Customer Religious Commitment on Customers Satisfaction and Loyalty of Islamic Banks in East Java. Al-Iqtishad: Journal of Islamic Economics, 7(2), 151-164. https://doi.org/10.15408/ijies.v7i2.1681
} 


\section{PENUTUP}

Penelitian ini menyimpulkan bahwa kualitas layanan maupun kepercayaan secara langsung belum mampu mempengaruhi loyalitas nasabah, namun kualitas layanan dan kepercayaan mampu memengaruhi loyalitas nasabah melalui kepuasan nasabah sebagai variabel mediasi.

Berdasarkan hasil penelitian ini, maka berikut beberapa saran yang dapat peneliti berikan: 1) penelitian ini diharapkan dapat menambah wawasan pengetahuan terkait dengan faktor-faktor yang dapat mempengaruhi loyalitas nasabah 2) penelitian ini diharapkan dapat menjadi salah satu sumber pertimbangan bank syariah untuk pengambilan keputusan dalam rangka peningkatan loyalitas nasabah terutama dari kalangan usia muda atau mahasiswa 3) penelitian ini diharapkan dapat menjadi salah satu sumber pertimbangan bagi pemerintah dalam hal ini Bank Indonesia untuk pengambilan keputusan dalam rangka pelaksanaan edukasi terkait Perbankan Syariah bagi mahasiswa 4) untuk penelitian selanjutnya disarankan untuk dapat menambahkan variabel independen serta dapat meneliti tidak hanya dari kalangan mahasiswa agar hasilnya lebih dapat mewakili dari komponen nasabah bank syariah secara keseluruhan.

\section{DAFTAR PUSTAKA}

Aisyah, M. (2018). Islamic Bank Service Quality and It's Impact on Indonesian Customers' Satisfaction and Loyalty. Al-Iqtishad: Jurnal Ilmu Ekonomi Syariah (Journal of Islamic Economics), 10(2), 367-388.

Azhar Muttaqin, D. A. D. (2017). Kualitas Produk, Pelayanan dan Nilai Syariah terhadap Persepsi Mahasiswa Ekonomi Islam untuk Menjadi Nasabah Bank Syariah. FALAH: Jurnal Ekonomi Syariah, 2(2), 196. https://doi.org/10.22219/jes.v2i2.5106

Dewi, K. A. N. (2016). PENGARUH KUALITAS LAYANAN TERHADAP LOYALITAS PELANGGAN MELALUI KEPUASAN PELANGGAN SEBAGAI VARIABEL INTERVENING (STUDI PADA PELANGGAN DUNKIN' DONUTS DI SURABAYA DAN SIDOARJO). BISMA - Bisnis Dan Manajemen, 9(1), 43-55.

Faisal, M., Shabbir, M. S., Javed, S., \& Shabbir, M. F. (2016). Measuring Service Quality and Customer Satisfaction in Pakistan: Evidence Based on Carter Model. International Business Management, 10(20), 5011-5016.

Fitriyana, F., Mustafid, \& Suparti. (2013). ANALISIS PENGARUH KUALITAS LAYANAN DAN KUALITAS PRODUK TERHADAP LOYALITAS PELANGGAN PADA ONLINE SHOP MENGGUNAKAN STRUCTURAL EQUATION MODELING. JURNAL GAUSSIAN, 2(2), 98108.

Ghozali, I., \& Latan, H. (2015). Partial Least Squares : Konsep, Teknik dan Aplikasi

Menggunakan Program SmartPLS 3.0 (Edisi 2). Universitas Diponegoro.

Haryono, T. (2010). Pentingnya menjaga dan meningkatkan hubungan baik dengan konsumen dalam masa krisis. JEJAK, 3(c), 75-82.

Hidayat, R., Akhmad, S., \& Machmud, M. (2015). Effects of Service Quality, Customer Trust and Customer Religious Commitment on Customers Satisfaction and Loyalty of Islamic Banks in East Java. Al-Iqtishad: Journal of Islamic Economics, 7(2), 151-164. https://doi.org/10.15408/ijies.v7i2.1681

Ishak, M. Z., \& Azzahroh, E. P. (2017). Pengaruh Kualitas Layanan Terhadap Loyalitas Nasabah Bank Syariah Dengan Kepuasan Nasabah Sebagai Variabel Intervening. Jurnal 
Pengaruh Kualitas Layanan dan Kepercayaan Nasabah terhadap Loyalitas Nasabah dengan Kepuasan Nasabah sebagai Variabel Mediasi

Ekonomi Dan Bisnis Islam (Journal of Islamic Economics and Business), 3(1), 26. https://doi.org/10.20473/jebis.v3i1.3599

Khotimah, N. (2018). pengaruh religiusitas, kepercayaan, citra perusahaan dan sistem bagi hasil terhadap minat nasabah menabung dan loyalitas di bank syariah mandiri (Studi Kasus Pada Nasabah Bank Syariah Mandiri Gresik). Jurnal Ilmu Ekonomi \& Manajemen, 05(01), 37-48.

Lapasiang, D., Moniharapon, S., Loindong, S., \& Ratulangi, U. S. (2017). Pengaruh Kepercayaan Dan Komitmen Terhadap Loyalitas Nasabah Pada Pt. Pegadaian (Persero) Cabang Karombasan Manado. Jurnal EMBA: Jurnal Riset Ekonomi, Manajemen, Bisnis Dan Akuntansi, 5(3), 3068-3077. https://doi.org/10.35794/emba.v5i3.17371

Mahyuni, \& Firdaus, M. R. (2014). Loyalitas Nasabah Pada Bank Mumalat Indonesia. Jurnal Wawasan Manajemen, 2(2), 119-137.

Malhotra, N. K. (2017). Riset Pemasaran Pendekatan Terapan. Indeks.

Muzaki, M. H., \& Ridlwan, A. A. (2019). Determinan Faktor Yang Memengaruhi Disloyalitas Nasabah Bank Pembiayaan Rakyat Syariah. Iqtishadia, 6(1), 1-12. https://doi.org/10.19105/iqtishadia.v6i1.2338

Ndubisi, N. O. (2007). Relationship marketing and customer loyalty. Marketing Intelligence \& Planning, 25(1), 98-106. https://doi.org/10.1108/02634500710722425

Ningtyas, F., \& Rachmad, B. (2011). Pengaruh Kepercayaan, Komitmen, Komunikasi, Penanganan Masalah Dan Kepuasan Nasabah Terhadap Loyalitas Nasabah Bank Muamalat Di Surabaya. Journal of Business and Banking, 1(1), 51. https://doi.org/10.14414/jbb.v1i1.152

OJK. (2019). Laporan Ekonomi Dan Keuangan Syariah.

OJK. (2019). Laporan Perkembangan Keuangan Syariah Indonesia.

Okatviani, E. (2012). Pengaruh Kualitas Layanan, Kepuasan Nasabah dan Citra Bank Terhadap Loyalitas Nasabah Bank Muamalat di Surabaya. Journal of Business and Banking, 2(2), 171-184.

Report, S. (2019). Stability report 2019.

Ridwan, H., Pusporini, \& Samin. (2018). Pengaruh Kepercayaan, Kualitas Pelayanan, Dan Nilai Nasabah Terhadap Loyalitas Pelanggan Melalui Kepuasan Sebagai Variabel Intervening Pada Bank BNI. "Pengabdian Pada Masyarakat Melalui Desiminasi Hasil - Hasil Penelitian Terapan."

Selnes, F. (1993). An Examination of the Effect of Product Performance on Brand Reputation, Satisfaction and Loyalty. European Journal of Marketing, 27(9), 19-35.

Sugiyono. (2018). Metode Penelitian Kuantitatif, Kualitatif dan R\&D. Alfabeta.

Tjiptono, F. (2019). Pemasaran Jasa. Penerbit ANDI.

Tjokro, C. I. (2018). DETERMINAN KEPUASAN NASABAH DALAM MEMBENTUK LOYALITAS NASABAH PT BTN CABANG AMBON. Jurnal Manajemen, Ide, Inspirasi (MINDS), 5(1), 119.

Warsito, C. (2015). The Image of Financial Institution as Islamic Bank In Mediation Service Quality and Customer Satisfaction on Customer Loyalty in Purwokerto. Al-Iqtishad: Journal of Islamic Economics, 7(2), 217-228. https://doi.org/10.15408/ijies.v7i2.1699 